https://doi.org/10.46344/JBINO.2021.v10i03.04

\title{
MICROBIOLOGICAL QUALITY OF SPICES MARKETED IN UTTARAKHAND, INDIA
}

\section{Deepti Gulati*, Nababrata Das²}

1*Associate Professor, Department of Biotechnology, Dolphin (PG) Institute of Biomedical and Natural Sciences, Dehra Dun-248007, Uttarakhand, India

2Department of Biotechnology, Dolphin (PG) Institute of Biomedical and Natural Sciences, Dehra Dun-248007, Uttarakhand, India

\section{Email : deepti_gulati01@yahoo.co.in}

\begin{abstract}
A total of 100 spice samples were investigated for the detection and enumeration of total aerobic mesophilic bacteria, thermotolerant coliforms (TC), Bacillus cereus, Staphylococcus aureus and Salmonella spp. All enumerations were performed according to the International Commission on Microbiological Specifications for Foods (ICMSF). For the total aerobic mesophilic bacteria counted $15 \%$ samples were acceptable, $80 \%$ were of marginal quality and $5 \%$ did not show any mesophilic count. $21 \%$ samples did not show any TC, $66 \%$ samples were acceptable whereas $13 \%$ were found unacceptable according to the limit set by ICMSF. Out of the total, $31 \%, 89 \%$ and $50 \%$ samples showed Salmonella spp., B. cereus and Staphylococcus aureus contamination respectively. Mechanical drying, cleaning, microbiological reduction treatment, irradiation, should be applied to spices to reduce microbial load and improve the safety of spices.
\end{abstract}

Keywords: Bacillus cereus, Mesophiles, Salmonella spp., Staphylococcus aureus, Thermotolerant coliforms 


\section{Introduction}

Spices are used worldwide to prepare food mainly due to their flavour, colour and aroma. They may be derived from many parts of the plant like bark, buds, flowers, fruits, leaves, rhizomes, roots, seeds, stigmas, style or the entire plant tops (Takeda et al., 2008). In Indian house-holds spices and herbs are invariably used for culinary purposes. Some of the most common ones are black pepper, cumin, fenugreek, clove, fennel, cardamom, cinnamon, coriander, paparika, sesame, mustard, bay leaves, garlic, onion. Many of these are grown and harvested in tropical climates where temperature conditions and high humidity support the growth of a wide variety of microorganisms. Indian spices exports have more than doubled in between 2008 to 2015 (Babu, 2017). In 2018, India's spice production was estimated to amount to 8.1 million metric tons.

Most of the Indian spices are in the effectively dried form to ensure stable stored product. In many of the spicegrowing countries, including India, the drying of the spices is mainly done by spreading them in open fields under the sun which might expose them to microbial contamination (Banerjee and Sarkar, 2003). These are then marketed without any treatment to reduce contamination. Also, during harvesting and processing, spices come in contact with dust, and faeces of rodents, birds and insects (Banerjee and Sarkar, 2003). All these contaminations can be transferred to food causing serious health problems in humans.
Reviewing scientific literature shows that several microorganisms including Bacillus cereus and other Bacillus spp., Clostridium perfringens, Staphylococcus aureus, Salmonella spp., E. coli, other members of Enterobacteriaceae, Aeromonas sp., yeast and mould have been frequently detected in spices (Schwab et al., 1982; Pafumi, 1986; Donia, 2008; Shamsuddeen, 2008; Ahene et al., 2011; Puchianu et al., 2012; Salari et al., 2012; Kimiran \& Gürün, 2013; Chaudhary \& Singh, 2014; Parveen et al., 2014; Ereifej et al., 2015; Bakobie et al., 2017). Salmonella has been previously isolated in $8.2 \%$ of different types of black pepper and $B$. cereus was isolated in all 33 spice samples studied in Australia (Pafumi, 1986). Mesophilic bacteria were found in ginger, black pepper, and red pepper in India (>106 CFU/g) in 50\% of the export quality spice samples (Seenappa \& Kempton, 1981).

Data from the above studies show that spices are a potential carrier of pathogenic microorganisms which cause diseases in humans. Despite of this fact, there are very few articles that report the evaluation of quality of these spices in India, where they are extensively produced, exported and consumed in almost all food preparations. More data is therefore required to evaluate the microbial quality of these spices so that proper decision about the treatment of these food additives can be taken. The aim of this study was therefore to estimate the microbiological quality of spices offered for sale to consumers in retail stores in Uttarakhand, India.

\section{Materials and Methods \\ Microorganisms used}


The reference organisms, used as control in the study, were Bacillus cereus (MTCC 8733), Staphylococcus aureus (MTCC 96), E. coli (MTCC 443) and Salmonella (MTCC 3231) (obtained from Microbial Type Culture Collection, Institute of Microbial Technology, Chandigarh, India).

\section{Sampling}

Spice samples were selected on the basis of information about the demand of a particular spice, obtained from wholesalers of specific spice trading areas. A total of 100 samples of spices were analysed for their microbiological quality. 10 samples (BP 01-BP 10) of black pepper (Piper nigrum), 10 samples (CL 01$\mathrm{CL}$ 10) of clove (Eugenia aromatic), 7 samples (BC 01-BC 07) of black cardamom (Amomum subulatum), 10 samples (Cl $01-\mathrm{Cl}$ 10) of cinnamon (Cinnamomum zeylanicum), 10 samples (CU 01-CU 10) of cumin (Cuminum cyminum), 7 samples (BL 01-BL07) of Indian bay leaves (Cinnamomum tamala), 10 samples (CM 01-CM10) of green cardamom (Elettaria cardamomum), 8 samples (FE 01-FE 08) of fenugreek (Trigonella foenum- graecum), 8 samples (KA 01-KA 08) of kalonji (Nigella sativa), 10 samples (DH 01-DH 10) of coriander (Coriandrum sativum) and 10 samples (GM 01-GM 10) of garam masala were collected between October 2018 and March 2019 from Uttarakhand, India. Samples were brought to the laboratory and analysed as soon as possible.

\section{Microbiological analysis}

Represented spices weighed at five grams (powdered samples), were homogenized in $45 \mathrm{ml}$ of buffered sterilized water having neutral $\mathrm{pH}$ by vortexing at normal speed for 1 minute. Serial decimal dilutions were prepared with the same diluent, and triplicate counting plates were prepared using appropriate dilutions. $0.1 \mathrm{ml}$ of the dilutions were spread on the surface of dried nutrient agar plates for colony forming unit (CFU) count. Determination of the most probable number (MPN) of TC was carried out according to the American Public Health Association guideline, using three-tube serial dilution. The MPN was calculated based on gas production in tubes of $E$. coli broth. The colonies were tested for detection of articulate pathogen coliform by the spread plate method on Eosin Methylene Blue agar (Hi Media M317) medium plates (Kornacki \& Johnson, 2001).

The pour plate method was used for mesophilic bacterial enumeration. One millilitre dilution of the sample was dispensed in a dish and mixed in $20 \mathrm{ml}$ nutrient agar (Hi Media M001). After spreading, the plate was kept in an incubator at $37{ }^{\circ} \mathrm{C}$ for 24 hours for CFU count. In order to calculate the final concentration, the number of CFU was multiplied by the inverse of the dilution factor of the respective plate (Morton et al., 2001).

For S. aureus enumeration, serial dilutions of food homogenates were plated on Baird-Parker agar (Hi Media M043) with $5 \%$ egg yolk tellurite emulsion, and incubated at $35^{\circ} \mathrm{C}$ for 48 hours. Characteristic colonies were counted and transferred to tubes containing nutrient agar. Random colonies were tested by Soyabean Casein Digest Agar (Hi Media M290) for catalase production 
and coagulase test was performed (Lancette et al., 2001).

For $B$. cereus enumeration, $0.1 \mathrm{ml}$ serial dilutions of food homogenates were plated on the Mannitol Yolk Polymixin Agar and incubated at $37{ }^{\circ} \mathrm{C}$ for 48 hours. After incubation, colonies were counted and random colonies were tested by Gram staining, Soyabean Casein Digest Agar (Hi Media M290) for catalase production and Simmons Citrate Agar ( $\mathbf{H i}$ Media M099) for citrate production (Tallent et al., 2012).

For detection and enumeration of Salmonella, represented spices weighed at five grams, were homogenized in $45 \mathrm{ml}$ of buffered peptone broth by vortexing at normal speed for 2 minutes and incubated for 18 to 20 hours at $370 \mathrm{C}$. After incubation, $0.1 \mathrm{ml}$ of the homogenate was transferred to $10 \mathrm{ml}$ of RappaportVassiliadis broth (Hi Media MH1491), and $1 \mathrm{ml}$ of the homogenate was transferred to $10 \mathrm{ml}$ of tetrathionate brilliant green broth (Hi Media M1255). These suspensions were incubated at $42^{\circ} \mathrm{C}$ and $35^{\circ} \mathrm{C}$ for 24 hours, respectively. After incubation, a loopful of each suspension was plated onto xylose-lysine-desoxycholate agar (Hi Media M031) and Salmonella-Shigella agar (Hi Media M108D). After incubation at $35^{\circ} \mathrm{C}$ for 24 hours, colonies were counted and random colonies from plates were biochemically tested using triple sugar iron agar (Hi Media MM021) (Andrews \& Sillikar, 2001).

\section{Statistical analysis}

All experiments were performed in triplicates. Data were analysed by determining standard error of the mean, two-way analysis of variance and simple correlation. Interpretation of results was done according to International Commission on Microbiological Specifications for Foods (ICMSF), 2005.

\section{Results and Discussion}

According to the International
Commission on Microbiological Specifications for Foods (ICMSF, 2005), the acceptable limit for total aerobic mesophilic bacteria is set at $<10^{4} \mathrm{cfu} / \mathrm{g}$ and limit for marginal quality is $10^{4}-10^{6}$ cfu/g. Above $10^{6} \mathrm{cfu} / \mathrm{g}$ it is not acceptable for consumption. The limit for coliforms is set at $10^{4} \mathrm{cfu} / \mathrm{g}$. The load of total aerobic mesophilic bacteria was found maximum $\left(7.52 \times 10^{5} \mathrm{cfu} / \mathrm{g}\right)$ in black pepper and minimum $\left(2.6 \times 10^{3} \mathrm{cfu} / \mathrm{g}\right)$ in cloves. In our study one sample each of kalonji, bay leaf, garam masala, black cardamom and clove did not show any mesophilic bacteria. Mesophilic bacteria were found in black pepper in India $>10^{6}$ cfu/g) in $50 \%$ of the export quality spice samples (Seenappa \& Kempton, 1981). In black pepper the counts of total aerobic mesophilic bacteria were found to range between $10^{4}$ and $10^{8} \mathrm{cfu} / \mathrm{g}$ (Krishnaswamy et al., 1974). Thermotolerant coliforms were found maximum $\left(7.68 \times 10^{5} \mathrm{cfu} / \mathrm{g}\right)$ in kalonji and minimum $\left(3.0 \times 10^{3} \mathrm{cfu} / \mathrm{g}\right)$ in fenugreek. 4 samples of bay leaves, 7 samples of garam masala, 1 sample of fenugreek, 6 samples of green cardamom and 3 samples of black cardamom did not show any thermotolerant coliform. Banerjee and Sarkar, 2003 showed that $51 \%$ samples out of 154 had unacceptable levels of TAMB (total aerobic mesophilic bacteria), coliforms 
and faecal coliforms were found in 33 and $15 \%$. Bacillus cereus, Staphylococcus aureus and members of Enterobacteriaceae occurred in 85, 59, 11 and $85 \%$ respectively of the samples. Our study showed a high load of Salmonella $\left(4.0 \times 10^{3}-6.76 \times 10^{5} \mathrm{cfu} / \mathrm{g}\right), B$. cereus $\left(2.0 \times 10^{3}-7.0 \times 10^{5} \mathrm{cfu} / \mathrm{g}\right)$ and $S$. aureus $\left(4.0 \times 10^{3}-7.12 \times 10^{5} \mathrm{cfu} / \mathrm{g}\right)$ in the spice samples. $31 / 100$ of the studied spice samples showed Salmonella, 89/100 showed B. cereus and 50/100 showed $S$. aureus contamination. Sagoo et al., 2009 detected Salmonella spp. in both $1 \%$ of dried spices and herbs sampled at retail and production. A small proportion of herbs and spices contained high count of B. cereus $\left(1 \%, \geq 10^{4} \mathrm{cfu} / \mathrm{g}\right)$. Moreira et al., 2009 analysed samples for Bacillus cereus, Staphylococcus aureus, and Salmonella. Their study showed that $5.6 \%$ of these samples were not in agreement with the standards of Brazilian law in highest quality. Zweifel and Stephan, 2012 assessed spices and herbs as source of
Salmonella-related foodborne diseases. Their study showed that the proportion of Salmonella-positive samples ranged from $0 \%$ to $8.4 \%$. Bedada et al., 2018 found $S$. aureus in $11.7 \%$ of 162 spice samples tested whereas Salmonella spp. was not noticed in any of the samples. The bacterial count in different spices studied is shown in Table 1. Number of samples within ICMSF range for total aerobic mesophilic bacteria and coliforms are shown in Table 2. The number of samples contaminated with Salmonella, B. cereus and $S$. aureus are shown in Table 3.

The computed analysis of variance showed no significant correlation ( $p \leq 0.05)$ between total aerobic mesophilic bacteria, Salmonella, B. cereus, S. aureus and thermotolerant coliforms. Cumin and coriander were found loaded with significantly $(p \leq 0.05)$ high doses of all the contaminants studied. On the other hand, Indian bay leaf and green cardamom were significantly ( $p \leq 0.05$ ) less contaminated.

Table 1: Microbiological count of unprocessed spices from India

\begin{tabular}{|l|l|l}
\hline Spices & No. of & Range of microbial count (cfu/g)
\end{tabular}

2021 May Edition | www.jbino.com | Innovative Association 


\begin{tabular}{|c|c|c|c|c|c|c|}
\hline & samples & $\begin{array}{l}\text { Total aerobic } \\
\text { mesophilic } \\
\text { count }\end{array}$ & Salmonella & B.cereus & S. aureus & Coliforms \\
\hline $\begin{array}{l}\text { Black } \\
\text { Pepper }\end{array}$ & 10 & $\begin{array}{l}1.32( \pm 0.13) \\
\times 10^{4} \\
7.52( \pm 0.01) \\
\times 10^{5}\end{array}$ & $\begin{array}{l}3.04( \pm 0.07) \\
\times 10^{4}-7.04 \\
( \pm 0.02) \times 10^{4}\end{array}$ & $\begin{array}{l}2.40( \pm 0.06) \\
\times 10^{3}-6.80 \\
( \pm 0.02) \times 10^{3}\end{array}$ & $\begin{array}{l}1.68( \pm 0.19) \\
\times 10^{4}-6.52 \\
( \pm 0.04) \times 10^{4}\end{array}$ & $\begin{array}{l}1.72( \pm 0.15) \\
\times 10^{4}-3.74 \\
( \pm 0.06) \times 10^{4}\end{array}$ \\
\hline Cumin & 10 & $\begin{array}{l}5.60( \pm 0.20) \\
\times 10^{5} \\
-5.72( \pm 0.33) \\
\times 10^{5}\end{array}$ & $\begin{array}{l}1.48( \pm 0.09) \\
\times 10^{4}-5.44 \\
( \pm 0.44) \times 10^{4}\end{array}$ & $\mid \begin{array}{l}2.0( \pm 0.63) \times \\
10^{3}-3.84 \\
( \pm 0.47) \times 10^{4}\end{array}$ & $\mid \begin{array}{l}4.0( \pm 0.09) \\
\times 10^{3}-4.64 \\
( \pm 0.05) \times 10^{4}\end{array}$ & $\begin{array}{l}1.52( \pm 0.37) \\
\times 10^{4}-3.20 \\
( \pm 0.10) \times 10^{4}\end{array}$ \\
\hline Cinnamon & 10 & $\mid \begin{array}{l}5.0( \pm 0.82) \\
\times 10^{3}-7.04 \\
0.08) \times 10^{5}\end{array}$ & $\begin{array}{l}4.0( \pm 0.38) \times \\
10^{3}-2.52 \\
( \pm 0.16) \times 10^{5}\end{array}$ & $\begin{array}{l}8.0( \pm 0.11) \\
\times 10^{3}-8.40 \\
( \pm 0.05) \times 10^{4}\end{array}$ & $\mid \begin{array}{l}8.0( \pm 0.41) \times \\
10^{3}-4.0 \\
( \pm 0.23) \times 10^{4}\end{array}$ & $\begin{array}{l}1.04( \pm 0.08) \\
\times 10^{4}-3.36 \\
( \pm 0.17) \times 10^{5}\end{array}$ \\
\hline Kalonji & 8 & $\mid \begin{array}{l}1.6 \quad( \pm \quad 0.19) \\
\times 10^{4}-3.84( \pm \\
0.08) \times 10^{5}\end{array}$ & $\begin{array}{l}2.04( \pm 0.26) \\
\times 10^{5}-6.76 \\
( \pm 0.09) \times 10^{5}\end{array}$ & $\begin{array}{l}4.8( \pm 0.34) \\
\times 10^{4}-7.0 \\
( \pm 0.31) \times 10^{5}\end{array}$ & $\mid \begin{array}{l}2.84( \pm 0.48) \\
\times 10^{5}-7.12 \\
( \pm 0.33) \times 10^{5}\end{array}$ & $\begin{array}{l}1.36( \pm 0.06) \\
\times 10^{4}-7.68 \\
( \pm 0.01) \times 10^{5}\end{array}$ \\
\hline Bay Leaves & 7 & $\mid \begin{array}{l}4.0( \pm 0.08) \\
\times 10^{3}-1.88 \\
0.03) \times 10^{4}\end{array}$ & nil & $\mid \begin{array}{l}1.6( \pm 0.05) \times \\
10^{4}-4.56 \\
( \pm 0.01) \times 10^{5}\end{array}$ & $\mid \begin{array}{l}4.0( \pm 0.38) \times \\
10^{3}-7.6 \\
( \pm 0.19) \times 10^{4}\end{array}$ & $\mid \begin{array}{l}3.2( \pm 0.04) \times \\
10^{4}-9.84 \\
( \pm 0.82) \times 10^{4}\end{array}$ \\
\hline $\begin{array}{l}\text { Garam } \\
\text { Masala }\end{array}$ & $\mid 10$ & $\mid \begin{array}{l}4.0( \pm 0.62) \\
\times 10^{3}-9.6 \\
0.37) \times 10^{4}\end{array}$ & $\begin{array}{l}4.0( \pm 1.1) \\
\times 10^{3}-2.0 \\
( \pm 0.83) \times 10^{4}\end{array}$ & $\begin{array}{l}1.2( \pm 0.17) \\
\times 10^{4} \\
( \pm 0.08) \times 10^{5}\end{array}$ & $\begin{array}{l}4.0( \pm 0.09) \times \\
10^{3}-4.16 \\
( \pm 0.13) \times 10^{5}\end{array}$ & $\begin{array}{l}9.2( \pm 0.46) \times \\
10^{4}-1.16 \\
( \pm 0.03) \times 10^{5}\end{array}$ \\
\hline Coriander & 10 & $\mid \begin{array}{l}1.12( \pm 0.01) \\
\times 10^{5}-3.96 \\
0.05) \times 10^{5}\end{array}$ & $\begin{array}{l}1.96( \pm 0.09) \\
\times 10^{5}-6.72 \\
( \pm 0.04) \times 10^{5}\end{array}$ & $\begin{array}{l}5.2( \pm 0.14) \\
\times 10^{4}-5.96 \\
( \pm 0.18) \times 10^{5}\end{array}$ & $\mid \begin{array}{l}4.0( \pm 0.93) \times \\
10^{3}-1.88 \\
( \pm 0.10) \times 10^{5}\end{array}$ & $\mid \begin{array}{l}4.0( \pm 0.05) \times \\
10^{3}-7.52 \\
( \pm 0.13) \times 10^{5}\end{array}$ \\
\hline Fenugreek & 8 & $\mid \begin{array}{l}4.0( \pm 0.72) \\
\times 10^{3}-8.8 \\
0.08) \times 10^{4}\end{array}$ & $\begin{array}{l}4.0( \pm 0.73) \\
\times 10^{3}-2.32 \\
( \pm 0.04) \times 10^{5}\end{array}$ & $\left|\begin{array}{l}8.4( \pm 0.07) \times \\
10^{4}-2.16 \\
( \pm 0.13) \times 10^{5}\end{array}\right|$ & $\mid \begin{array}{l}4.0( \pm 0.51) \times \\
10^{3}-3.88 \\
( \pm 0.18) \times 10^{5}\end{array}$ & $\mid \begin{array}{l}3.0( \pm 0.09) \times \\
10^{3}-5.6 \\
( \pm 0.02) \times 10^{4}\end{array}$ \\
\hline $\begin{array}{l}\text { Green } \\
\text { Cardamom }\end{array}$ & 10 & $\mid \begin{array}{l}4.0( \pm 0.28) \\
\times 10^{3}-2.56 \\
0.12) \times 10^{4}\end{array}$ & nil & $\begin{array}{l}8.0( \pm 0.35) \\
\times 10^{3}-2.6 \\
( \pm 0.61) \times 10^{5}\end{array}$ & $\left|\begin{array}{l}4.0( \pm 0.97) \times \\
10^{3}-1.6 \\
( \pm 0.48) \times 10^{4}\end{array}\right|$ & $\mid \begin{array}{l}8.0( \pm 0.05) \times \\
10^{3}-3.2 \\
( \pm 0.08) \times 10^{4}\end{array}$ \\
\hline $\begin{array}{l}\text { Black } \\
\text { Cardamom }\end{array}$ & 7 & $\mid \begin{array}{l}1.6( \pm 0.62) \\
\times 10^{4}-1.92 \\
1.21) \times 10^{5}\end{array}$ & nil & $\mid \begin{array}{l}4.8( \pm 0.93) \times \\
10^{4}-1.84 \\
( \pm 0.47) \times 10^{5}\end{array}$ & $\begin{array}{l}4.0( \pm 0.80) \times \\
10^{3}-2.8 \\
( \pm 0.86) \times 10^{4}\end{array}$ & $\begin{array}{l}4.0( \pm 0.39) \times \\
10^{3}-6.4 \\
( \pm 0.09) \times 10^{4}\end{array}$ \\
\hline Cloves & 10 & $\mid \begin{array}{l}2.6( \pm 0.74) \\
\times 10^{3}-4.64 \\
0.43) \times 10^{4}\end{array}$ & $\begin{array}{l}4.0( \pm 0.42) \\
\times 10^{3}-1.2 \\
( \pm 0.76) \times 10^{5}\end{array}$ & $\begin{array}{l}2.0( \pm 0.78) \\
\times 10^{3}-2.32 \\
( \pm 0.84) \times 10^{4}\end{array}$ & $\begin{array}{l}1.40( \pm 0.91) \\
\times 10^{4}-3.16 \\
( \pm 0.40) \times 10^{5}\end{array}$ & $\mid \begin{array}{l}3.40( \pm 0.21) \times \\
10^{3}-3.44 \\
( \pm 0.18) \times 10^{5}\end{array}$ \\
\hline
\end{tabular}

Data represented as Mean $\pm \mathrm{SE}(\mathrm{n}=3)$

Table 2: ICMSF range for total aerobic mesophilic bacteria and coliforms

\begin{tabular}{|c|c|c|c|}
\hline Spices & $\begin{array}{c}\text { No. of } \\
\text { samples }\end{array}$ & $\begin{array}{c}\text { No. of samples within ICMSF range } \\
\text { (Total aerobic mesophilic bacteria) }\end{array}$ & Coliforms \\
\hline
\end{tabular}




\begin{tabular}{|c|c|c|c|c|c|}
\hline & & \begin{tabular}{|l}
$<10^{4}$ cfu/g \\
(Acceptable)
\end{tabular} & $\left|\begin{array}{l}10^{4-}-10^{6} \mathrm{cfu} / \mathrm{g} \\
\text { (Marginal) }\end{array}\right|$ & $\mid \begin{array}{l}>10^{6} \text { cfu/g } \\
\text { (Unacceptable) }\end{array}$ & \begin{tabular}{|l}
$>10^{4}$ cfu/g \\
(Unacceptable)
\end{tabular} \\
\hline $\begin{array}{l}\text { Black } \\
\text { Pepper }\end{array}$ & 10 & 0 & 10 & 0 & 0 \\
\hline Cumin & 10 & 0 & 10 & 0 & 0 \\
\hline Cinnamon & 10 & 4 & 6 & 0 & 3 \\
\hline Kalonji & 8 & 1 & 7 & 0 & 4 \\
\hline Bay Leaves & 7 & 2 & 5 & 0 & 0 \\
\hline $\begin{array}{l}\text { Garam } \\
\text { Masala }\end{array}$ & 10 & 2 & 8 & 0 & 1 \\
\hline Coriander & 10 & 0 & 10 & 0 & 4 \\
\hline Fenugreek & 8 & 5 & 3 & 0 & 0 \\
\hline \begin{tabular}{|l|} 
Green \\
Cardamom
\end{tabular} & 10 & 2 & 8 & 0 & 0 \\
\hline $\begin{array}{l}\text { Black } \\
\text { Cardamom }\end{array}$ & 7 & 1 & 6 & 0 & 0 \\
\hline Cloves & 10 & 3 & 7 & 0 & 1 \\
\hline
\end{tabular}

Table 3: Spice samples contaminated with Salmonella, B. cereus and S. aureus

\begin{tabular}{l|l|l|l|l|} 
Spices & No. of samples & \multicolumn{3}{|c|}{ Number of contaminated spice samples } \\
\cline { 3 - 5 } Black Pepper & 10 & Salmonella & B. cereus & $\mid$ S. aureus \\
Cumin & 10 & 5 & 4 & 4 \\
Cinnamon & 10 & 4 & 7 & 5 \\
Kalonji & 8 & 5 & 10 & 3 \\
Bay Leaves & 7 & 0 & 8 & 8 \\
Garam Masala & 10 & 2 & 7 & 4 \\
Coriander & 10 & 4 & 10 & 5 \\
\hline Fenugreek & 8 & 4 & 10 & 4 \\
Green & 10 & 0 & 8 & 4 \\
Cardamom & & 10 & 4 \\
Black & 7 & 0 & 7 & 5 \\
Cardamom & & 3 & 8 & \\
Cloves & 10 & 3 & & \\
\hline
\end{tabular}

\section{Conclusion}

As per the specifications of the ICMSF, our study indicates high level of microbial contamination in spices which are extensively used in the Indian cuisines. This microbial contamination may have an 
adverse effect on health depending on the method of preparation of food and the time of addition of the spices to food. Steps need to be taken to improve the quality of spices before they are marketed. Mechanical drying, cleaning, microbiological reduction treatment, irradiation, can reduce microbial load and therefore can improve the safety of spices.

\section{Declarations}

Conflict of Interest: The authors declare that they have no conflict of interest.

Authors' contributions: The $1^{\text {st }}$ author contributed to the concept, work plan, analysis of data and writing of manuscript. $2^{\text {nd }}$ author did the survey, sample collection and lab work. Both authors read and approved the final manuscript.

Funding: None. The authors provided personal resources for funding this paper.

\section{Acknowledgements}

The authors are thankful to Dolphin (PG) Institute of Biomedical and Natural Sciences, Dehra Dun, Uttarakhand, India, for providing the necessary laboratory requirements and facilities to carry out this work. This research work did not receive any funding from any source.

\section{References}

1. Abou Donia, M. A. (2008). Microbiological quality and aflatoxinogenesis of Egyptian spices and medicinal plants. Global Veterinaria, 2(4), 175-181.

2. Ahene, R. E., Odamtten, G. T., \& Owusu, E. (2011). Fungal and bacterial contaminants of six spices and spice products in Ghana. African Journal of Environmental Science and Technology, 5(9), 633-640.

3. Andrews, W. H., Flowers, R. S., Silliker, J. \& Bailey, J. S. (2001). Salmonella. Compendium of methods for the microbiological examination of foods, American Public Health Association, Washington, DC. In F. P. Downes and K. Ito (ed.),

357.

https://doi.org/10.2105/9780875531755ch $\underline{37}$

4. Babu, P. H. (2017). Export performance of spices in India: An empirical study. Parikalpana: KIIT Journal of Management, 13(1), 66-74. https://doi.org/10.23862/kiitparikalpana/2017/v13/i1/151275

5. Bakobie, N., Addae, A. S., Duwiejuah, A. B., Cobbina, S. J., \& Miniyila, S. (2017). Microbial profile of common spices and spice blends used in tamale, Ghana. International Journal of Food Contamination, 4(1), 10. https://doi.org/10.1186/s40550-017-0055-9 6. Banerjee, M., \& Sarkar, P. K. (2003). Microbiological quality of some retail spices in India. Food Research International, 36(5), 469-474. https://doi.org/10.1016/s09639969(02)00194-1

7. Bedada, T. L., Derra, F. A., Gebre, S. G., Sima, W. G., Edicho, R. M., Maheder, R. F., ... \& Asefa, Y. B. (2018). Microbial evaluation of spices in Ethiopia. The Open Microbiology Journal, 12(1), 422-429. https://doi.org/10.2174/1874285801812010 $\underline{422}$

8. Chaudhary, P., \& Singh, P. (2014). Isolation, identification and molecular characterization of microflora obtained from spices and spice mixes. World 
Journal of Pharmaceutical Research, 3(2), 2020-2030.

9. Erdem, A. K., Aydoğdu, E. Ö. A., \& Gürün, S. (2013). Bacteriological analysis of the red pepper spices marketed as packaged and unpackaged in Istanbul. European Journal of Biology, 72 (2), 23-30.

10. Ereifej, K. I., Feng, H., Rababah, T. M., Tashtoush, S. H., Al-U'datt, M. H., AlRabadi, G. J., ... \& Alkasrawi, M. (2015). Microbiological status and nutritional composition of spices used in food preparation. Food and Nutrition Sciences, 6(12),

1134. https://doi.org/10.4236/fns.2015.612118 11. International Commission on Microbiological Specifications for Foods (ICMSF). (2005). Spices, herbs, and dry vegetable seasonings. In Microorganisms in Foods 6, Microbial Ecology of Food Commodities, 2 nd Ed. ICMSF (ed) Kluwer Academic/Plenum Publishers, London, 360.

12. Kornacki, J. L. \& Johnson, J. L. (2001). Enterobacteriaceae, coliforms and Escherichia coli as quality and safety indicators. Compendium of methods for the microbilogical examination of foods, 69-82.

https://doi.org/10.2105/9780875531755ch $\underline{08}$

13. Krishnaswamy, M. A., Patel, J. D., Nair, K. K. S., \& Muthu, M. (1974). Microbiological quality of certain spices. Indian Spices, 11 (1 and 2), 6.

14. Lancette, G. A., \& Bennett, R. W. (2001). Staphylococcus aureus and staphylococcal

enterotoxins. Compendium of methods for the microbiological examination of foods, American Public Health Association, Washington, DC. In F. P.
Downes and K. Ito (ed.), 4, 387-403. https://doi.org/10.2105/9780875531755ch $\underline{39}$

15. Moreira, P. L., Lourencao, T. B., Pinto, J. P. D. A. N., \& Rall, V. L. M. (2009). Microbiological quality of spices marketed in the city of Botucatu, Sao Paulo, Brazil. Journal of food protection, 72(2),

$421-424$. https://doi.org/10.4315/0362-028x-

\subsubsection{1}

16. Morton, R. D. (2001). Aerobic plate count. Compendium of methods for the microbiological examination of foods, American Public Health Association, Washington, DC. In F. P. Downes and K. Ito (ed.), 4, 63-67. https://doi.org/10.2105/9780875531755ch $\underline{07}$

17. PAFUMI, J. (1986). Assessment of the microbiological quality of spices and herbs. Journal of Food Protection, 49(12), 958-963. https://doi.org/10.4315/0362028x-49.12.958

18. Parveen, S., Das, S., Begum, A., Sultana, N., Hoque, M. M., \& Ahmad, I. (2014). Microbiological quality assessment of three selected spices in Bangladesh. International Food Research Journal, 21 (4), 1327-1330.

19. Puchianu, G., Necula, V., Babii, M., \& Enache, D. (2012). Research on Some Microbiological Quality of Natural Spices Used in the Food. Academy of Romanian Scientists, 1(2), 92-104.

20. Sagoo, S. K., Little, C. L., Greenwood, M., Mithani, V., Grant, K. A., McLauchlin, J., ... \& Threlfall, E. J. (2009). Assessment of the microbiological safety of dried spices and herbs from production and retail premises in the United 
microbiology, 26(1),

$39-43$. https://doi.org/10.1016/i.fm.2008.07.005 21. Salari, R., Habibi, N. M., Boroushaki, M. T., Mortazavi, S. A., \& Fathi, N. M. (2012). Assessment of the microbiological quality and mycotoxin contamination of Iranian red pepper spice. Journal of Agricultural Science and Technology, 14, 1511-1521.

22. Schwab, A. H., Harpestad, A. D., Swartzentruber, A., Lanier, J. M., Wentz, B. A., Duran, A. P., ... \& Read, R. B. (1982). Microbiological quality of some spices and herbs in retail markets. Applied and Environmental Microbiology, 44(3), 627630.

\section{https://doi.org/10.1128/aem.44.3.627-} 630.1982

23. Seenappa, M., \& Kempton, A. G. (1981). A note on the occurrence of Bacillus cereus and other species of Bacillus in Indian spices of export quality. Journal of Applied Bacteriology, 50(2), = 225-228. https://doi.org/10.1111/j.13652672.1981.tb00885.x
24. Shamsuddeen, U., \& Ameh, J. B. (2008). Survey on the Possible Critical Control Points during the Production of "Balangu" in Kano. Bayero journal of pure and applied sciences, 1 (1), 76-79.

25. Takeda, J., De Silva, S., Muthuraman, P., Rahman, S. M., \& Kawet, L. (2008). Spices in Sri Lanka, India and Bangladesh with special reference to the usages and consumptions. Agri Bull, 93, 125.

26. Tallent, S. M., Kotewicz, K. M., Strain, E. A., \& Bennett, R. W. (2012). Efficient isolation and identification of Bacillus cereus group. Journal of AOAC International, 95(2), 446-451. https://doi.org/10.5740/jaoacint.1 1-251 27. Zweifel, C., \& Stephan, R. (2012). Spices and herbs as source of Salmonellarelated foodborne diseases. Food Research International, 45(2), 765-769. https://doi.org/10.1016/i.foodres.2011.02.0 $\underline{24}$ 